\title{
USA Policy toward Iran -The Impacts of United States Sanctions on Iran's Behaviors in the Region in Donald Trump's Term
}

Mahmoud Shaaban Bayoumi Aly

Istanbul Aydin University, Turkey

DOI: $10.36347 /$ sjahss.2021.v09i01.004

| Received: 09.01.2021 | Accepted: 20.01.2021 | Published: 23.01.2021

*Corresponding author: Mahmoud Shaaban Bayoumi Aly

Abstract

Original Research Article

This research paper sought to ascertain the US sanctions against Iran regime especially in the period of Donald Trump's term, the first chapter of the paper is the introduction part of the topic which seek to explain the historical background of the US-Iranian relations beginning from the $40^{\text {th }}$ of the last century, and the role of the Soviets in the middle east and in Iran, and the Soviets role in shaping the relations between Iran and USA. based on the research paper, it is ascertained that the US sanctions on Iran started early in the last century, especially after the Iranian revolution in 1979, these American sanctions against Iran formed a new form of the relationship between the two countries considering a great historical impact that appeared since the government of Muhammad Mossadegh was overthrown from power by the CIA and its British counterpart in the 1940s.Consequently, the US sanctions on Iran are, according to the research paper, the starting point from which Iranian American relations always spring and its impact on the interests of the two countries in the Middle East and in the neighboring countries of Iran such as Iraq and Syria, and even America's allies in the Gulf [1]. Iran and the United states had made their efforts in the previous years to affect the policy in the Middle East and in the Decision-making circles in wherever their interests overlap and collide. This principle of foreign policy of the two countries which based on the complete pragmatism had been the cause of major clashes between them over the past years. So, The Complete Fluctuations, were, the backbone of the relations between Iran and US since 1950 till right now. Their Relations ranged between strong links and connections, and full enmity, Another notable relationship that is highlighted in the introductory part of the research paper is that In The period of the 40th of the last century, the US tutelage and control, were clear over the Iranian relations and even the Decision-making in the country, so one of the reasons which lead for the Islamic revolution in Iran was the rejection of the complete American hegemony over the policy and administration in Iran, so Muhammad Reza Shah Pahlavi, allowed US to support his regime, against the Iranian citizens who considered him as the "US Shah", so there were clear steps in this aspect, Washington did not stand idly with its pro-American man in Iran but worked hard to aid him, like the steps of the American Administration to establish military bases in the north of Iran to spy on the Soviets in this time also, through sending American military advisers to monitor and preserving US interests in Iran and controlling The Iranian parliament. Also, US role in the Iranian scene was complicated, it wanted to draw new policy with new characters, new allies and new political interference that allows for it to be in the future the only one which control Iran the great country in the region especially with the emergence of oil and Iran geographical value in the middle east, so the American role did not stop at this limit, but it and the British government helped Muhammad Reza Shah Pahlavi to strength his rule, through arranging coup against Mohammad Mossadeq, the Iranian prime minister in this period, who was democratically elected and secular leader, in 1953. There is another aspect captured in the introductory part of the paper is explaining the reasons why there was need to carry out this research paper, according to the research paper there was need to show the emergence of the oil in the middle east as it was the key word in the radical transformation in the Iranian-US relations. Washington took new radical action toward the government of Mohammad Mossadeq after strong decisions made by this government during this period. The American Administration supported the coup against Mohammad Mossadeq and brought Muhammad Reza Shah Pahlavi back to the rule in Iran, especially after Mohammad Mossadeq decisions of nationalizing the Iranian oil sector and the refuse of Washington for this step. The relations continued strongly between US and Muhammad Reza Shah Pahlavi after the coup in 1953, through supporting him through a cooperation nuclear agreement between the two countries in 1957 , then the United States provided Iran with nuclear reactor for peaceful use in 1967. In the security field, the United States also helped Muhammad Reza Shah Pahlavi to establish the Iranian ministry of intelligence and national security "SAVAK", which helped to control the security in Iran from 1957 till 1979 the time of Islamic revolution after many 
years of injustice and absence of freedom [2]. Another aspect related to the topic of the research paper is the role of the security tools as a solution to confront all voices that oppose policies and decisions, before the iranian revolution, especially with the rise of many voices rejecting economic policies and the Iranian American rapprochement during this period. So, This Iranian ministry of intelligence and national security was the tool by which Muhammad Reza Shah Pahlavi could suppress and arrest thousands of people who refuse his rule, also could keep eyes on the opponents in and out of Iran. In addition, the aim of the research paper shows the effects of the Iranian revolution on the relations with USA and the countries in the middle east and the role of Ruhollah Khomeini in this revolution and the new Iranian regime, that came after the Islamic revolution and its new policies towards USA and the countries in the middle east especially after the of attack the American embassy in Tehran on 4 November 1979 and detaining 52 employees of the embassy. these events in Iran, which refuse completely the American role in the political scene, forced USA to cut its ties with Iran in April 1980, then Iran had released the 52 employees in the American embassy in the beginning of the president Ronald Reagan term in 1981 [3]. The purpose of the research paper was to explain the history of the external factors which affect the relations between Iran and USA. Like the role of Iran in Iraq, Syria, Lebanon. Yemen and other places in the middle east, as Iran had not changed its intellectual and political convictions towards the United States of America, rather it insisted on its stance of categorically rejecting any American role in the middle east region, and it sought to promote that Washington seek to control the region completely, this Iran's antiAmerica policy in the middle east lead US president George HW Bush to announce that in 2002 that Iran is labeled in the axis of evil, this step caused the Islamic republic to be anger. Even in the term of Muhammad Khatami from 1997 till 2005, some were counting on his policy to make change in Iran's policy toward USA, after his call for dialogue with Washington, but nothing new happened [4]. Also, the region faced a new shape of struggle between the two countries depending on the historical legacy between Iran and USA, according to another aspect of the research papers, so the two countries' relations created a new shape of struggle, which changed the region completely, so the tensions had escalated in the relations between Iran and USA, from 1979. Even after the end of Khomeini's term and new period started by the rule of the leader Ali Khamenei, Iran applied the same policy against USA, in all fields start from the nuclear program, Iraq, Syria, and in all fields where any struggle between the two countries. Other section in the research paper related to the research questions and research objectives especially in the period of Donald trump's term. Another aspect is the research method that highlighted the way of the analysis approaches used in the research study for collecting data regarding to the study, and the qualitative approach in which the study was written. In the end of the first chapter, it sums the US-Iranian relations from 1940 till the period of 2005 and the start of Mahmoud Ahmadinejad term in Iran .As the long period of time covered in the first chapter witnessed many events and details in the relations of Iran and America. Then the second chapter after that deals with the period of Mahmoud Ahmadinejad and Barack Obama until 2013, when Ahmadinejad's rule ended, and what this period witnessed the negotiations of the Iranian nuclear program and US sanctions on Iran and Iran's military role in the Middle East region. Then followed the third chapter, which dealt with the period of Hassan Rouhani and the end of Barack Obama's rule, where he witnessed the signing of the Iranian nuclear agreement in 2015 - and then the chapter also included the start of Donald Trump's period, and the launch of the maximum pressure policy that Trump adopted to confront the Iranian regime in the region completely, in the final of the paper is the conclusion part, which presents a summary of all the details discussed in the research paper [18].

Keywords: Relations, sanctions, military, revolution, USA, Iran, Middle East, gulf, war, Syria.

Copyright $\odot 2021$ The Author(s): This is an open-access article distributed under the terms of the Creative Commons Attribution 4.0 International License (CC BY-NC 4.0) which permits unrestricted use, distribution, and reproduction in any medium for non-commercial use provided the original author and source are credited.

\section{INTRODUCTION}

According to the research paper the history of the long relations between the United States and Iran from 1950 till 2005, included a set of profound determinants and changes that these relations had witnessed considering the radical changes that had happened in the Middle East and indeed in the whole world in these years. On the other hand, the US-Iranian relations during these periods were not a single pace, but witnessed fluctuations at one time, and convergence at other time, and attempted at rapprochement at another time [1], the distances remained far apart between the two countries in general in front of observers, while there were secret negotiations between the two countries over these years. As according the research paper and the beginning of the time of the thesis. The period of the strong relations between Iran and USA started from the Allied occupation of Iran in the world war II and continues in the 1950s, 1960s and in 1970 s of the last century until Khomeini's return to his country and the victory of the Iranian revolution in 1979. In these long years, the relations between America and Iran were in a great harmony and in a state of complementarity between the two countries. For America in this period, Iran was like a strong ally that has no alternative in the Middle East, especially with the growth of the oil in the region and America's desire for Iran to be its arm facing by the gulf countries [2].

The research paper discovered that the feature of this period was complete Iranian subservience to the American decision, and the Shah was like an obedient disciple of the white house, a situation that caused an increase in the opposition against the Iranian rule during this period. As a result, Iran was one of the countries 
that USA relied on to extend its influences in the Middle East since the 1950s till right now and thus this period was a treasure for the American side. On the other hand, Iranians was in a great agreement with the American administration which helped it to achieve some economic renaissance in addition to the conclusion of agreements belong to peaceful nuclear program and economic developments [1] also according to the research paper There is no doubt that the period that witnessed the estrangement between the two countries was linked to the huge political transformations in the middle east country after the Islamic revolution. The Iranian revolution, led to qualitative change in the relations with USA, as it was accompanied by independence and hostile tendencies to the US influence, and many issues played an important role in bringing relations between them to the stage of estrangement [3].

The research paper discovered that after 1979, revolution, Carter's administration tried to build a relationship with the new regime, but it failed. So that is why the Iranian-US relations were described by as hostile, as they were based at that stage on accusing each other by several accuses. Finally, USA succeeded to put Iran under the economic sanctions since the Islamic revolution and as a result. New era of struggle started between the United States of America and the Iranian republic [3] also the research paper found that as a result of the clash that occurred between the two countries after the Islamic revolution, there were stations of direct conflict between the USA and Iran, foremost of which was the storming of the US embassy in Tehran and the arrest of employees and diplomats from inside it. This important incident in the history of iranian foreign policy was one of the major motives that pushed the united states to enter secret negotiations with Iran, to reach a solution for the release of its diplomats in Iran. This incident was the first stage that witnessed secret negotiations between the two countries after the revolution [4].

There was another incident, according to the research paper which was the taking of American hostages in Lebanon, in a response to America and France's arming Iraq with weapons in the Iraqi-iranian war 1980 till 1988, the American hostages were arrested in Lebanon by groups supported by Iran, so Tehran with the negotiations between the two countries in 1985 they succeeded to solve what was known by the name of "the Iran- contra" scandal, and reached a deal in which Iran would buy American weapons in exchange for the release of the hostages in Lebanon [3]. During the period of attempts at rapprochement with the united states of America, Iran did not seek to create a state of twining, political harmony, or even a partnership with the united states of America in the middle east region, but it was evading the international pressures that it suffers from, and escaping from the isolation it had faced since the Islamic revolution in
1979 by seeking to reach out to Washington, for understanding about some common issues between the two countries [5]. Hence, the complex history between the two countries did not allow at all to create a political partnership between them in light of the permanent enmity, but as a result of the difficult political situation that Iran had suffered from and is still suffering from at the present time, it was trying to tell world public opinion that it did not object to negotiate or understand with its first enemy in the world, which is the unites states of America [6] So, Rafsanjani's rule witnessed many attempts for this rapprochement, as well as in the late period of Muhammad Khatami, it also witnessed attempts to reach an understanding with the united states of America in some fields, but all these attempts failed because of the prior image of the two countries between them, an impression that would destroy any attempts to bring views between the two countries, as it was so already [6].

Also, according to the research paper, The United States of America adopted two different policies towards Iran during the period in which President Ahmadinejad was in power from 2005 to 2013, as the features of the American foreign policy towards Iran during the era of President George W. Bush differed from the policy adopted by President Barack Obama [7], So, The United States of America has sought to change the ruling political system in Iran since the success of the Iranian revolution in 1979, and former US President George W. Bush tried to change the regime by Supporting demonstrations in Iran and pressures on the nuclear program, but in the term of Barack Obama, according to the research paper, he sought to build a positive relations with Iran through the nuclear agreement [8].

Finally, as the research paper discovered that the policies of the United States of America against Iran since the Islamic Revolution in 1979 have depended on the philosophy of conflict management, as the direct and continuous clash between the two parties throughout these long years, but US policy changed during the era of former US President Barack Obama, as Obama relied in his policies on the philosophy of settlement and not Philosophy of conflict and clash with Tehran. Former US President Barack Obama was able, through the settlement philosophy he adopted in his policies with the Islamic Republic, to achieve great successes, including the signing of the nuclear agreement with Iran in 2015, an agreement that angered the Republican Party in America, and pushed Trump after coming to power in the White House, to the severe attack on Obama and pulling out of the nuclear deal again in 2018 [9]. And as the research paper [8].The beginning of the real clash between the administration of Donald Trump and Iran was the nuclear agreement, especially since the US President believed that Obama's participation in the nuclear agreement was a rescue for the Iranian regime, which was trying to get rid of its 
major economic problems that it was suffering from, so Trump's policies and statements were all since His candidacy in the 2016 presidential elections is in the direction of absolute clash and hostility with the Iranian Republic, which has caused a lack of confidence between the two parties and an increase in tension in the Middle East [9].

\section{LITERATURE REVIEW}

The Iranian-US relations include many complex details that are worthy of examination and research to derive results for present and future generations, The Iranian-US relations since 1979 after the Islamic Revolution are in state of escalation of positions, based on divergent actions in many issues raised regionally and internationally. Starting from the Iranian Revolution to the present, Iranian-US relations became more complicated due to the political volitions of the two countries. Iran still plays essential role in the political scene in what belong to the American foreign policy toward the Middle East. But in some periods, there were some facilities in the way of managing the US-Iranian relations, these facilities allowed in the second presidential term of former US president Barak Obama to be there a serious step toward the historical agreement of the Iranian nuclear deal [8].

In the second term of former US president Barak Obama, White House believed with the direct negotiations with Iran, so in 2013 US announced that it agrees to cooperate directly with Hassan Rouhani regime. The US desire for negotiations with Iran, was an introduction for the Iranian nuclear deal in 2015. But after Obama's term, Donald Trump adopted new policy toward Iran; he abandoned Iran nuclear deal and withdraws from the former Obama agreement with the Islamic republic [8]. In this situation if there was comparison between Obama policy toward Iran and Trump's one, it is easy to discover great gap between the two policies. The significance of the thesis topic here is to discuss the impacts of Donald Trump policy toward Iran and to clear the role of Obama policy toward Iran, making comparison between each other's [8].

Although Iran does its best to make benefits from 2015 nuclear deal, but in general we must confirm that the White House had differ policy toward Iran in the period of Donald Trump. The significance of the thesis topic is to clear for who interest in the international relations, that there are several ways to make successful negotiations, and lead the researchers to discover the best way during the comparison between Obama and Trump policy [10]. No doubt that Donald Trump's policies and sanctions toward Iran caused complicated difficulties to the Islamic republic, in its economy, policy even in its connections with the neighbors. So, Iran's behaviors in the region changed from the reactions to action behaviors. Tehran refused to face the Sanctions imposed by US alone, its new policy after the sanctions depended on forcing other countries on confront and targeting the US strategic interests, allies in the region [10]. To refusing sanctions, Iran seized oil tankers in strait of Hurmuz, caused crisis in the prices of oil around world, targeting oil companies in Saudi Arabia like ARAMCO finally supported Houthi group with extra weapons to target strategic interests inside the Saudi territory. These actions by Iran targeted US allies in the Middle East. Tehran also targeted the US strategic interests in Iraq, like the United States military bases and the US embassy in Iraq. Iran and the United states had made their efforts in the previous years to affect the policy in the Middle East and in the Decision-making circles in wherever their interests overlap and collide. This principle of foreign policy of the two countries which based on the complete pragmatism had been the cause of major clashes between them over the past years. [10]. So, The Complete Fluctuations, were, the backbone of the relations between Iran and US since 1950 till right now. Their Relations ranged between strong links and connections, and full enmity [11]. Finally, Iran became s source for creating policy in the region and in the American foreign policy trends, so studying the Iranian role is an important field to those seek to realize the complexities of policy in Middle East.

\section{RESEARCH ELABORATIONS}

According to the above results of the research paper, it is quite evident that the policies of the United States of America against Iran since the Islamic Revolution in 1979 have depended on the philosophy of conflict management, the relations faced several clashes between the administration of Donald Trump and Iran also between Barack Obama and Iran and other administrations of the white house with Iran. The nuclear agreement and the nuclear program is the basic problem between the two countries especially after the iranian revolution. [12].

Also, The Iranian-US relations include many complex details that are worthy of examination and research to derive results for present and future generations, The Iranian-US relations since 1979 after the Islamic Revolution are in state of escalation of positions, based on divergent actions in many issues raised regionally and internationally. Starting from the Iranian Revolution to the present, Iranian-US relations became more complicated due to the political volitions of the two countries. Iran still plays essential role in the political scene in what belong to the American foreign policy toward the Middle East. But in some periods, there were some facilities in the way of managing the US-Iranian relations, these facilities allowed in the second presidential term of former US president Barak Obama to be there a serious step toward the historical agreement of the Iranian nuclear deal [12]. 


\section{RESULTS/FINDINGS}

According to the previous details, the region faced constant tension due to America's policies against the Islamic Republic, and the Iranian response to the US sanctions, especially Washington's dealings with Iran were based on directing successive and powerful strikes simultaneously in order not to give Iran the opportunity to respond. However, the research paper concluded that US policies pursued by the Donald Trump administration were not aimed at overthrowing the entire Iranian regime, changing it, or even changing the political philosophy on which the Iranian regime relies in its moves and expanding its military and political influence in the region [13]. Rather, the White House targeted what could be called an assessment of Iranian behavior in the region and reset its orientations away from US interests and the interests of America's allies in the Middle East region, as it sought to strike strikes against the Iranian regime to paralyze its moves and reduce the continuity of its influence in the region, but without ending this influence. Especially Iran represents a strategic value for American influence in the Middle East. Where America can, through the scarecrow of Iranian influence in the Middle East, pass its military deals and policies in the region with ease and acceptance by its allies in the Middle East, like what happened from the normalization agreements that America supported and sponsored between Israel, the Emirates, Bahrain, and Sudan, depending on the scarecrow of Iranian influence in the region [10].

But on the other hand, according to the research paper, the American policies adopted by the Trump regime failed to evaluate Iran's behavior in the Middle East region, especially Tehran has the vast experience it has gained over decades, these experiences help it cope with any size of US sanctions and absorb American pressure, and to benefit from it internally and externally, and to reproduce its political and military discourse in the region and internally, depending on the harsh policies imposed by Washington against it [14].

Also, the research paper believed that the proxy wars began because of the conflict in the USIranian case, whether in Iraq, Lebanon, Syria, or The Iranian-Saudi case, where the proxy conflict in Yemen is through the Iranian-backed military arm, the Houthi group Therefore, the proxy war about Iran is the use of military arms and armed elements in Iraq, Syria, Lebanon, Yemen, and Afghanistan to confront the United States of America and its allies in the Middle East. also, Iran has sought through the proxy war to pressure the United States of America to withdraw its forces from Iraq and sought to put pressure on allies of America in the Middle East to blackmail them and pressure them, to escape from America's sanctions and reduce the severity of American pressure, like what happened several times against Saudi Aramco by the Houthis and Iraqi military arms backed by Iran [10].
The research paper results, included, the results of the US sanctions, as Despite the size of the US sanctions imposed by the Donald Trump administration on the Iranian Republic, which varied between military, political and social sanctions, and even though the Iranian economy has been severely affected by these sanctions, the US administration has not achieved many results from its goals towards pressure on Iran [15]. Iran has great experience in dealing with US and European sanctions policies. Indeed, Iran can easily benefit from the sanctions and its climate and exploit them well for the benefit of its nuclear program and its political expansion in the Middle East, as it was able to exploit the US elections and the ongoing sanctions by the Trump administration and resorted to announce their continuation. In uranium enrichment, taking advantage of the state of political fluidity in America considering the US elections [15]. Iran has been able to create alternatives, albeit not strong, to confront the US sanctions in the economic field [15].

Finally, The American policy towards Iran, especially the sanctions, has strengthened Iran's illegal activities in smuggling and selling oil, and even in exploiting the resources of others, such as Iranian economic activity in Africa, all of which are activities to compensate for its losses due to US sanctions [17]. Iran fully understands that the US administration wants to reduce Tehran's influence in Syria, and that America is giving the green light to the Israeli presence in Syria through the continuous bombing by Israel of Iranian and Syrian targets inside Syria [17]. On the other hand, America understands ending the alliance between Iran and Syria will not happen at all. Rather, breaking the alliance between Iran and the Bashar al-Assad regime will be in the interests of Russia, America's main enemy in the Middle East [17].

\section{CONCLUSIONS}

According to the previous details, the research paper holds that Trump did not want to end, change, or eliminate the Iranian regime, or create the atmosphere for a new regime through a revolution or military change, for example. However, the research paper holds that the Trump administration sought to re-refine the Iranian role in the region only, and not to eliminate the Iranian role in the region [17]. As also the research paper holds that America believes that the alliance of Iran and Bashar is less dangerous than the alliance of Russia and the regime of Bashar al-Assad. Therefore, America's policies against Iran in Syria aim to reduce its influence and reposition it again in the region and not to amputate or end it [16].

\section{REFERENCES}

1. Sick G. All fall down: America's tragic encounter with Iran. Viking Pr; 1986.

2. Keddie, Nikki R and Gasiorowski Mark J. (Eds.). Neither East Nor West: Iran, the Soviet Union, and 
the United States. New Haven, USA, Yale University Press; 1990.

3. Parsi T. Losing an enemy: Obama, Iran, and the triumph of diplomacy. Yale University Press; 2017.

4. Youssief AYMAN. Iran in America's Strategic Calculations: From Dual Containment to the New Middle East. Retrieved from https://bit.ly/3iQazDe (YOUSSIEF, 2008)

5. Ali M OATAZ. A history of American defeats against Iran. Why is America afraid of declaring war?2019. Retrieved from https://bit.ly/3c9ITXk ( ali, 2019)

6. BBC. The official announcement of a "historic" agreement on Iran's nuclear program.2015. Retrieved from https://bbc.in/3hzMdxp

7. Stokes D, Wilson N, Wilson N. Small business management and entrepreneurship. Cengage Learning EMEA; 2010.

8. Phares W. The Choice: Trump vs. Obama-Biden in U.S. Foreign Policy (1st ed.). 2020. Retrieved from https://amzn.to/2WNVEQc

9. Kerr PK and Katzman K. Iran Nuclear Agreement and U.S. Exit. 2018; Retrieved from https://bit.ly/2LDCt9s

10. Ben-Meir A. Trump: The Wannabe Dictator: How We Got to This Dire State of Affairs (1st ed.). 2020; Retrieved from https://amzn.to/3rwyBb8
11. Amirahmadi H. The United States and the Middle East: A Search for New Perspectives (1st ed.). New York, USA: State University of New York Press; 1992.

12. Conley RS. Presidential Leadership and National Security: The Obama Legacy and Trump Trajectory (1st Edition, Vol. 1). 2017; Retrieved from https://amzn.to/3aNZamd

13. Al Baker BDOUR. The future of Iranian influence in the Middle East region under US sanctions. 2019; Retrieved from https://bit.ly/3513t9W

14. Woodward B. Fear: Trump in the White House (1st ed.). 2019; $\quad$ Retrieved from https://amzn.to/3hmnJYr

15. Hussain $\mathrm{N}$ and Ahmed M. Rising Iran: Implications for the Middle East and Pakistan. Researchgate. 2016; 24-35. Retrieved from https://bit.ly/3mSo8TA

16. Juneau T. No, Yemen's Houthis actually aren't Iranian puppets. The Washington Post. 2019; 1, 12. Retrieved from https://bit.ly/37OkpCj

17. Alavi SA. Iran and Palestine: Past, Present, Future. 2019; Retrieved from https://amzn.to/3poXK1U

18. Abu Al-Qasim MH. What is the future for the shaky deal between Europe and Iran?. 2019; Retrieved from https://bit.ly/2XeUYUB. 